Mitteilungen der Österreichischen Geographischen Gesellschaft, 160. Jg., S. 143-162

(Annals of the Austrian Geographical Society, Vol. 160, pp. 143-162)

Wien (Vienna) 2018, https://doi.org/10.1553/moegg160s143

\title{
Regional Ecotourism Networks: Experiences AND Lessons from Los TuXtlas, MeXico
}

\author{
Christoph Neger and Enrique Propin FrejomiL, \\ both Mexico City* \\ Initial submission / erste Einreichung: 04/2018; revised submission / revidierte Fassung: 10/2018; \\ final acceptance / endgültige Annahme: 11/2018 \\ with 3 figures in the text
}

\section{CONTENTS}

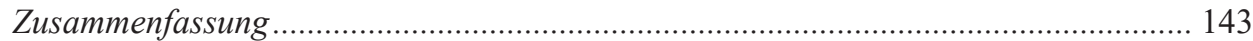

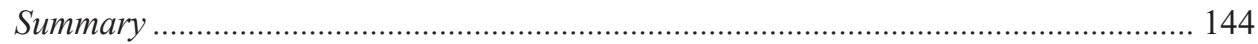

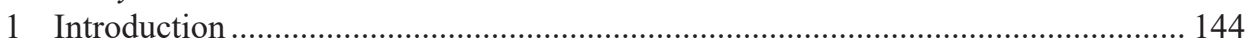

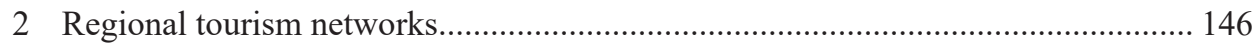

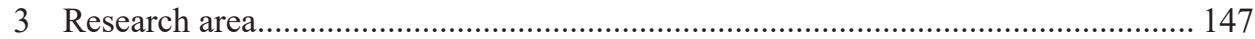

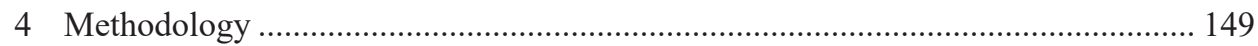

5 Development, structure and effects of ecotourism networks ............................... 150

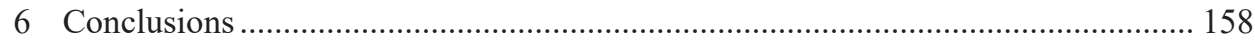

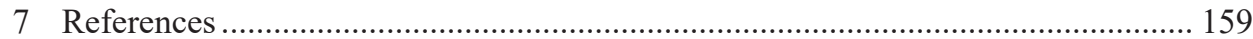

\section{Zusammenfassung}

Regionale ÖKOTOURISMUS-NETZWERKE: ERFAHRUNGEN UND LEHREN AUS Los TuXtlas, MeXiko

Der Ökotourismus hat das Potenzial, die menschliche Entwicklung in marginalisierten Regionen zu fördern und zugleich zum Umweltschutz beizutragen. Studien haben jedoch gezeigt, dass Ökotourismus-Unternehmen oftmals Schwierigkeiten haben, wirtschaftlich rentabel zu sein. In diesem Zusammenhang werden Kooperationen und die Einrichtung von Netzwerken auf regionaler Ebene als erfolgversprechende Strategien ins Treffen geführt, um die Unternehmen in unterschiedlicher Weise zu unterstützen, zum Beispiel durch Informationsaustausch, effektive Werbung, Erstellung wettbewerbsfähiger Produkte und die Vertretung gemeinsamer politischer Interessen. Die vorliegende Studie untersucht auf

\footnotetext{
* Doctoral candidate Christoph Neger, MSc., National Autonomous University of Mexico, Postgraduate Studies in Geography, Circuito de Posgrados S/N, C.P. 04510 Mexico City, Mexico; email: ch.neger@gmail. com; - Senior researcher Dr. Enrique Propin Frejomil, National Autonomous University of Mexico, Institute of Geography, Investigación Científica, CP. 04510 Mexico City; email: propinfrejomil@igg.unam.mx
} 
Basis eines methodisch gemischten Ansatzes, inwiefern sich dies in der Region Los Tuxtlas im südlichen Mexiko bestätigen lässt. Seit dem Jahr 2000 wurden hier mehrere Versuche unternommen, regionale Ökotourismus-Netzwerke zu etablieren. Eine kartographische Darstellung und die Verwendung von Methoden der quantitativen Netzwerkanalyse, auf Basis einer Befragung, zeigen die aktuelle Struktur sowohl formeller Netzwerke als auch das Netz informeller Kooperationen in der Region. Das Zusammenführen dieser Daten mit qualitativen Informationen aus Interviews schafft einen Einblick in die Auslöser der Netzwerk-Prozesse und beleuchtet die involvierten Stakeholder und die wichtigsten Hindernisse sowie die Kosten und den Nutzen der Teilnahme in regionalen Netzwerken.

Schlagwörter: Ökotourismus, Mexiko, Region Los Tuxtlas, regionale Netzwerke, quantitative Netzwerkanalyse, formelle Netzwerke, informelle Kooperationen

\section{Summary}

Ecotourism has the potential to foster human development in marginalised areas and, at the same time, promote environmental conservation. However, as studies have shown, ecotourism enterprises often struggle to be economically viable. In this context, cooperation and the establishment of networks on a regional scale have been proposed as promising strategies, which can benefit the enterprises in many ways, including information exchange, effective promotion, creation of competitive tourism products and representation of common political interests. Based on a mixed-method approach, the present investigation analyses to what extent this has been the case in the Los Tuxtlas region in Southern Mexico, where since the year 2000 several attempts have been made to form regional ecotourism networks. Mapping and the use of quantitative network analysis tools, based on the application of questionnaires, demonstrate the current structure of both formally established networks and the net of informal cooperation in the region. In combining these data with qualitative information obtained from interviews, insights are gained regarding the catalysts that initiate networking processes and the stakeholders involved, the main obstacles as well as costs and benefits of forming part of regional networks.

Keywords: Ecotourism, Mexico, Los Tuxtlas region, regional networks, quantitative network analysis, formal networks, informal cooperations

\section{Introduction}

Ecotourism is promoted worldwide and especially in developing countries with the promise of reconciling human development and the conservation of nature. Through the income generated by visitors it is supposed to motivate locals to take care of their natural heritage (Honey 2008). While the concept has been defined in many different ways (cp. FENNELL 1999), one widely recognised definition was developed within the framework of the World Ecotourism Summit in 2002. It specified that ecotourism should be in line with economic, social, and environmental sustainability. In order to differentiate it from other forms of sustainable tourism, ecotourism additionally has to embrace an active contribu- 
tion to conservation and to the well-being of the local and indigenous communities of the places visited, and include them in planning and operation of the touristic development. Furthermore, visitors should receive some form of interpretation of the natural and cultural heritage (World Tourism Organization and United Nations Environmental Programme 2002).

Since the concept's origins in the 1980 s as part of the discussion on alternative tourism, ecotourism has been widely criticised as having contributed to environmental destruction in just the same way as conventional forms of tourism (JAFARI 2001; WEAVER 2006). However, authors like FARrell and RunYAn (1991) and Honey (2008) point out that these negative effects are due to a wrong application of the concept and its misuse for the promotion and greenwashing of conventional tourism offers. They argue that, on the contrary, genuine ecotourism has indeed shown to bring about positive effects for the environment.

These positive effects have been reported in Mexico, too (cp. Secretaría de Turismo et al. 2007), where ecotourism has been growing rapidly, supported by NGOs and governmental institutions dedicated to environmental conservation and social development (LóPEZ and PALOMINo 2008). Yet in this country the implementation of ecotourism has been faced by another problem: its economic sustainability. According to a study realised by Secretaría de Turismo et al. (2007), out of 61 community-based ecotourism initiatives in different states, none had proven to be economically viable. Private ecotourism enterprises were economically sustainable in a few cases, though.

Several of the enterprises analysed by the study of Secretaría de Turismo et al. were located in the Los Tuxtlas Biosphere Reserve (LTBR) and its surroundings, an area with a high potential for the development of ecotourism, due to its biodiversity and variety of attractive natural landscapes including mountains covered by rainforest, lakes, rivers and cascades, costal lagoons, mangrove forests, sand beaches and cliff lines. More recent studies by LeIn (2011), Piñar-Állarez (2011), Neger (2013), Díaz-CARrión and Neger (2014) and JUÁREZ (2016) on different aspects of ecotourism in the area revealed that while some private ecotourism enterprises managed to be profitable, and the number of enterprises had increased considerably, many community-based initiatives were still highly dependent on governmental subsidies. Thus, low economic benefits kept restricting the role of ecotourism as a tool for conservation and human development.

Both in academia as well as in the realm of public institutions, regional tourism networks are often seen as a factor of success for small ecotourism enterprises and small and medium tourism firms in general (cp. HALL et al. 2007; LYNCH and MORRISON 2007; PARÉ and LAZOS 2003; SARETZKi et al. 2002; Secretaría de Turismo et al. 2007; United Nations Environmental Programme and World Tourism Organization 2005; ZEHRER and RAICH 2010). In Los Tuxtlas, several attempts have been made into this direction. The principal research question of the present investigation is how these networks have impacted on the development of ecotourism. In relation to this main question also the development and current structure of networks in the region, catalysts and obstacles for the networking process and the role of external actors are analysed.

The paper starts with a theoretical outline to give a basic understanding of regional tourism networks. In the following part it confines the research area and describes the ba- 
sic environmental, social, and economic condition under which ecotourism is developing in Los Tuxtlas. Subsequently, it explains the methodology applied in the investigation and, finally, discusses the results of the study.

\section{Regional tourism networks}

Networks are, generally speaking, systems of lines, which connect different nodes. In spatial networks these nodes can be geographically located whereas the lines can be both physical elements as well as virtual connections. The nodes can be spatial units like cities, regions or countries, but also, as it is the case with tourism networks, social actors like individuals, groups, organisations, enterprises, and institutions (KNIELING and KUNZMANN 2005, cited in Tölle 2012; PARNReITER 2018; Tölle 2012). In the context of networks in tourism, relations can be classified as horizontal, between firms, which offer the same type of services, and as vertical, between different actors within the structure of the tourism market, like hotels, tourism guides, tour operators, travel agencies, etc. (VARISCO 2007).

Horizontal integration - the main interest of the present investigation - is a challenging process, since the enterprises involved are direct competitors. In order to being able to work together, the firms need to operate under a scheme of 'coopetition', which means that they are at the same time competing in the market and cooperating strategically in complementary activities (SALDAÑA et al. 2012). Tourism networks can exist on different geographical scales. Regional networks, however, are of special interest, due to the tendency of tourists to view a whole region as one tourism product (SARETZKI et al. 2002). This territorialisation oriented towards the touristic demand is commonly called a tourism destination (cp. BeCKer 2007; EISENSTEIN 2014; FreYer 2006; ViKen 2014, ZeHrer and RAICH 2010). Consequently, in the tourism market, there is not only a competition between different tourism service providers but also between destinations.

Concerning studies on networks in destinations, the central issue is how actors cooperatively realise complementary activities in order to obtain potential synergetic effects (HALl et al. 2007). One essential field of action is the destination's collective promotion (Michael and Hall 2007). Another important field is the diffusion and exchange of knowledge. Thereby, as LYNCH and Morrison (2007, p. 60) put it, networks benefit the actors " $[\ldots]$ by leveraging knowledge and resources they would not otherwise readily gain and thereby aiding their competitive capabilities and effectiveness". Other fields are the assurance and enhancement of the quality of the services offered by the firms, which are involved in the network (VARISCO 2007), the representation of common political interests and the possibility to put together resources for projects, which couldn't be afforded by one single small or medium enterprise and to collaboratively create tourism products, which enhance the region's competitiveness (LYNCH and MORRISON 2007; ZEHRER and RAICH 2010).

Despite all these potential benefits, the networking process also generates costs. Therefore, it is necessary to evaluate the relation between costs and benefits of different networking activities, network designs and forms of organisation, depending on their circumstances and the objectives of the network's participants, instead of blindly advocating 
networks and cooperation as a kind of panacea (ZEHRER and RAICH 2010). The relationship between the actors involved in a network can be established formally, for instance under the guidance of a public institution dedicated to the promotion of the tourism destination, as a private-public network or as a self-organised business network (BECKER 2007; VIKEN 2014). The latter can also appear in an informal way; such an informal network might be a predecessor to a formal network (LYNCH and MORRISON 2007; VARISCO 2007).

For networks to be successful, their participants should share collective visions and goals and develop a strong level of trust among each other, which enables the sharing of knowledge and other types of collaboration. Depending on the various aspects mentioned before, there are differences in the density of interactions and the degree of social embeddedness of the stakeholders and, in general, in the configuration of the network's structure (LYNCH and MorRison 2007). As Hall et al. (2007, p. 145) observes, networks “[...] exist in myriad forms, and each emerges according to the needs and values of the local participants that make them up".

\section{Research area}

Los Tuxtlas is a region in the South of the Mexican state of Veracruz. Its main landscape feature is the Sierra de Los Tuxtlas, a volcanic mountain range, which extends over an area of 3,299.4 $\mathrm{km}^{2}$. While most of its surface is hill country below 1,000 meters above sea level, there are some higher peaks with an altitude of up to 1,680 meters above sea level. The area is surrounded by the Gulf of Mexico and the coastal plains of the gulf (Geissert 2004; Guevara et al. 2004). The main water bodies of the region are the Lake of Catemaco and the Lagoon of Sontecomapan.

This topography and the area's tropical climate (cp. GUTIÉRREZ-GARCÍA and RICKER 2011) cause the presence of different types of vegetation (including tropical rain forest, cloud forest, and mangrove) and a rich biodiversity (GUEvara et al. 2004). Therefore, in 1998, the Mexican federal government established a biosphere reserve covering a surface of 1,551.2 km² (Comisión Nacional de Áreas Naturales Protegidas 2006), a type of natural protected area, which was conceptualised by UNESCO's Man and Biosphere Programme. The main goal of these reserves is to accomplish a harmonisation of human development and conservation of nature (United Nations Educational, Scientific and Cultural Organization 1996).

In this context, it is important to mention that Los Tuxtlas is relatively densely populated. According to the Mexican census of 2010, within the boundaries of the reserve the number of inhabitants was 28,183 . However, the nine municipalities, which share parts of the surface of the Sierra de Los Tuxtlas - Ángel R. Cabada, Santiago Tuxtla, San Andrés Tuxtla, Catemaco, Hueyapan de Ocampo, Soteapan, Mecayapan (split into two separate areas), Tatahuicapan de Juárez and Pajapan - together made up a number of 417,696 inhabitants. In the northwestern municipalities, Ángel R. Cabada, Santiago Tuxtla, San Andrés Tuxtla and Catemaco, the population is almost entirely mestizo, while in the southwestern municipalities, $51.6 \%$ belong to the indigenous Nahua and Popoluca people (calculations based on data from Instituto Nacional de Estadística y Geografía 2013b). In the 
LTBR's management plan, these groups of municipalities are classified as two subregions, named after their main mountains, San Martín Tuxtla in the northwest and Santa Marta in the southeast (Comisión Nacional de Áreas Naturales Protegidas 2006).

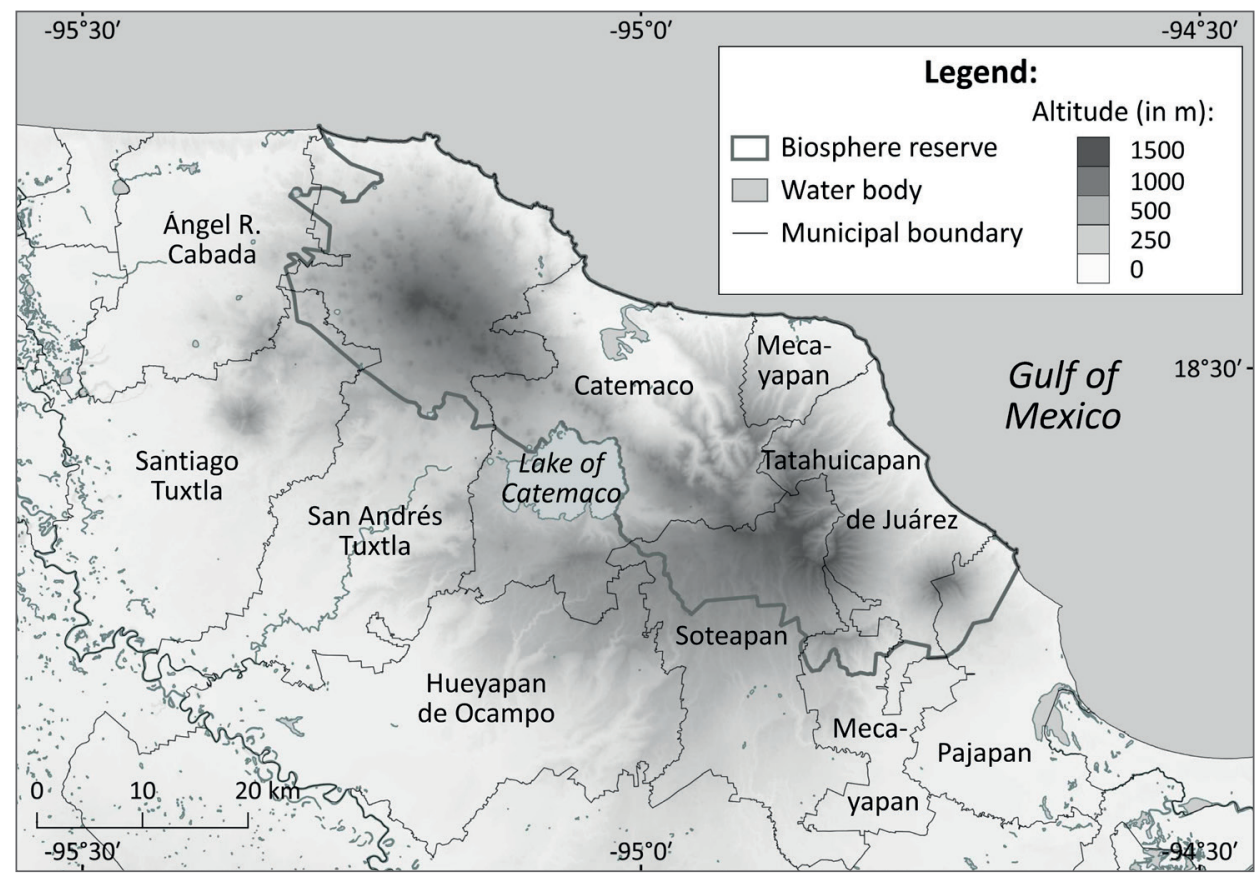

Source: Prepared by the authors, based on data from Instituto Nacional de Estadística y Geografía (2013a, 2016a) and Comisión Nacional de Áreas Naturales Protegidas (2015)

Figure 1: Basic overview of the Los Tuxtlas region

Los Tuxtlas can be considered a marginalised region, with a poverty rate (defined as having less income than required for purchasing a basket of basic food and non-food items) of $78.3 \%$, far above the Mexican average of $51.7 \%$ (Consejo Nacional de Evaluación de la Política de Desarrollo Social 2017). It is a structurally weak area, with a high dependence on primary activities. These conditions create a high pressure on the region's natural resources. Over the last decades, Los Tuxtlas has lost most of its original vegetation. Based on data from remote sensing, Guevara et al. (2004) calculate a decrease of forest cover of $56 \%$ from 1972 to 1993 . Since the establishment of the biosphere reserve, land cover change has decreased, but it hasn't stopped completely (Proyecto Sierra de Santa Marta 2011).

Tourism plays an important part in the economy of the municipalities San Andrés Tuxtla and Catemaco and to a lesser degree in Santiago Tuxtla, while the other municipalities have very little touristic infrastructure (cp. Instituto Nacional de Estadística y Geografía 
2016b). Visitors are attracted to the region by the natural landscapes mentioned above as well as by Catemaco's fame as a centre of witch doctors (PARÉ and LAzos 2003).

\section{Methodology}

The present investigation uses a mixed method approach, integrating both quantitative and qualitative data. This integration, as PARNREITER (2018) points out, allows it to take advantage of the strengths of both approaches in order to obtain a more complete comprehension of the phenomenon of interest. Along the same lines, KocH and KüHN (2011) object to a strict separation between qualitative and quantitative methods in qualitative network analysis. They point out that, in addition to enriching the research findings, the triangulation of data helps to avoid wrong interpretations.

This combination of different methods of investigation and analysis is especially useful in the comparison of, on the one hand, formally established networks, which might or might not lead to actual cooperation of the involved stakeholders, and, on the other hand, the structure of ties which really exist between the stakeholders. The latter might be implicated in a formal network, but might also have evolved as a result of an informal networking process. Qualitative research methods give information on the establishment of the formal networks, while quantitative methods prove useful in the analysis of the actual structure of connections and the resulting network(s). Qualitative research can further question how these relationships have come to place and which impacts they have had.

The starting point for the research was a revision of academic literature on ecotourism in Los Tuxtlas, in order to find information on the historical development of the region's ecotourism networks (see chapter 1). This provided the basis for the next part of the investigation, field work in the research area, starting with two preliminary visits in November 2016 and April 2017; interviews and questionnaires were then applied in two further visits in November 2017 and March 2018.

A crucial step at the beginning of the field work was the elaboration of a catalogue of genuine ecotourism enterprises. The classification was based on a set of indicators related to the definition of the World Ecotourism Summit, outlined in chapter 1. Two important criteria in this context were, firstly, if the enterprises carried out concrete actions for biodiversity conservation like preservation, reforestation and surveillance of forest areas, and, secondly, if they provided tourists with some kind of environmental education or interpretation of nature. As a result, several self-proclaimed ecological tourism firms, which didn't realise any of these measures, were excluded from the study.

In the next step, representatives of all 18 detected ecotourism enterprises were asked to respond to a structured questionnaire. The objective of this was to obtain concise and comparable quantitative data on the current connections between ecotourism enterprises and their relations to external stakeholders. The ecotourism enterprises' representatives were presented with a predefined list of all the other actors and had to indicate whether or not they had different types of connections with them. These ties were further valued, for instance regarding the frequency of interactions. 
In a further step, semi-structured interviews were carried out with representatives of the ecotourism enterprises, aimed at a deepening of the understanding on the networking processes they had undergone. In a final step, external stakeholders who had been mentioned to having been involved in the regional ecotourism networks, or who had been considered as being responsible for supporting these networks, were taken into account. Semi-structured interviews were carried out with representatives of ten stakeholders from governmental organisations, NGOs, and businesses. In order to analyse the information of the interviews, latent content analysis (cp. DunN 2010) was applied, aimed at understanding the meaning of the interviewees' responses and distinguishing the main themes, which appeared in the transcripts of the interview texts. In order to do this, codes were ascribed to the text, which in a next step permitted the combination of text sections from different interviews on the same theme.

An important step for analysing the data from the questionnaires was the manual integration of the network data in a geographic information system and their visualisation. This was carried out using the open source software QGIS. ${ }^{1)}$ Data on formal networks was ascribed to the points locating the ecotourism enterprises, allowing their representation through symbols. The informal ties were shown as valued graphs connecting these points. So it was possible to determine how geographical proximity and aspects of the region's geography impact into the networking processes. Only the present structure of ties was visualised, as the responses to the questionnaire proved the observation of TER WAL and Boschma (2009, p. 11), who stated that it is "[...] unfeasible and unrealistic to ask respondents about their relationships in the (remote) past".

In addition to its visualisation, data from the questionnaires regarding the relationships of the ecotourism enterprises were represented in matrices. This permitted the calculation of indicators - like the rate of trust each enterprise received from its counterparts - and measures from quantitative social network analysis, using the software UCINET. ${ }^{2)}$ The matrix used for the UCINET calculations was undirected and all resulting values were normalised (cp. КоCH and KüHN 2011; RENDóN et al. 2007).

The geographically referenced visualisation of the network data showed that there was a correlation between spatial distance and the intensity of networking relationships. In order to further investigate this aspect, the road distances between the places, where ecotourism enterprises are established were calculated, based on information from Google Maps. ${ }^{3)}$

\section{Development, structure and effects of ecotourism networks}

Figure 2 shows the 18 ecotourism enterprises identified for the present study, out of which 11 are located within the boundaries of the LTBR. Two thirds of them are considering themselves as community-based firms, characterised by cooperative ownership of

\footnotetext{
1) https://qgis.org/en/site/ (accessed Sept. 9, 2017).

2) https://sites.google.com/site/ucinetsoftware/home (accessed Feb. 1, 2018).

3) https://www.google.com/maps/ (accessed March 10, 2018).
} 
several members of a local community, out of which five are located in communities with a majority of indigenous population, in the Santa Marta subregion. The other enterprises are private firms, mainly small family businesses owned by locals; only in one case the owner is from Córdoba in central Veracruz.

Nanciyaga had already been established in 1987. The next foundations, in the late 1990s, were Selva del Marinero and El Apompal. Most than half of the ecotourism enterprises, both private and community-based, existing in Los Tuxtlas today, were established in the first decade of the new millennium. The last ones were La Otra Opción, Los Arrecifes, Ceytaks and Kan Tasejkan, which all opened their doors to the public in 2011. The majority are microbusinesses, with a workforce of less than 10 full-time equivalents (FTE). Only Nanciyaga and Laguna del Ostión are larger, with a workforce of 37.5 FTE and 36 FTE, respectively. The visitors of the ecotourism centres are almost entirely domestic tourists, mainly from Mexico City and other parts of the state of Veracruz.

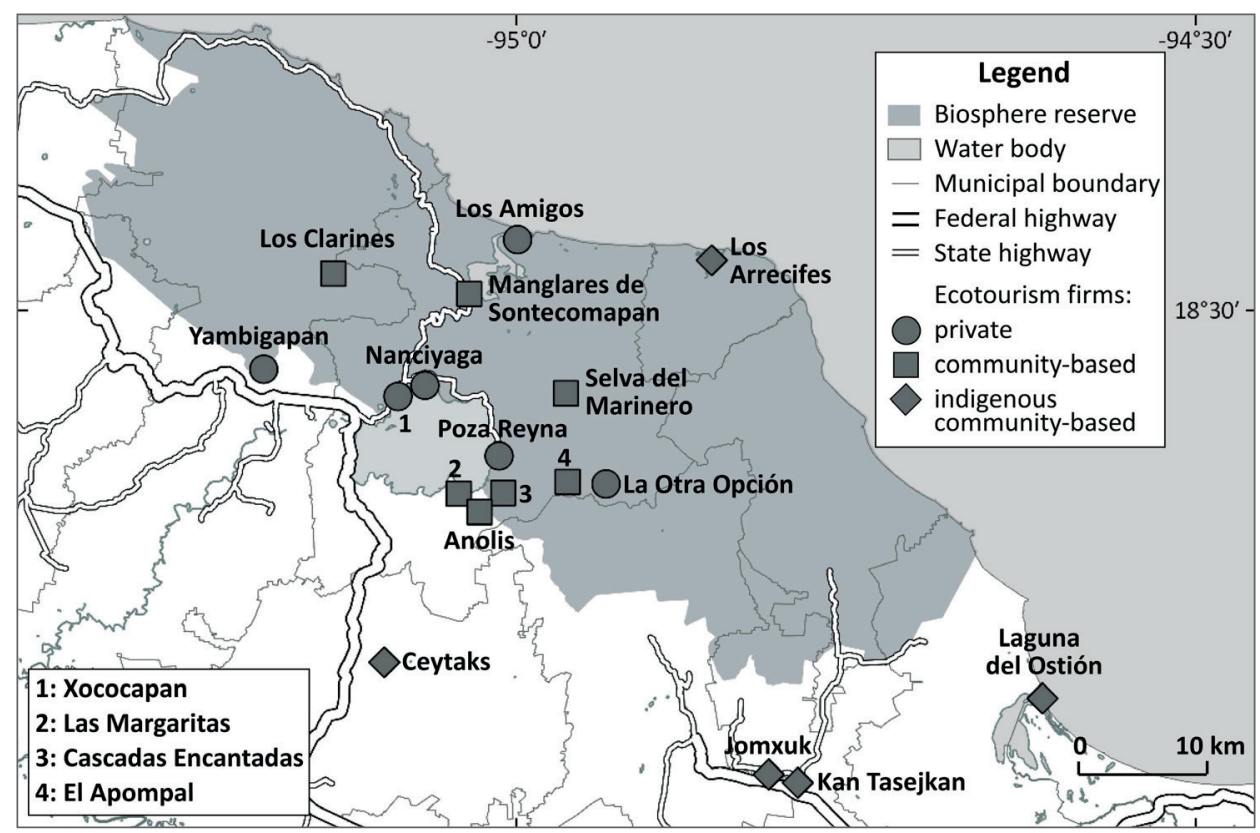

Source: Prepared by the authors, based on fieldwork and data from Instituto Nacional de Estadística y Geografía (2016a) and Comisión Nacional de Áreas Naturales Protegidas (2015)

Figure 2: Distribution of ecotourism enterprises in Los Tuxtlas

\subsection{Development and current structure}

Figure 3 shows both the membership of the ecotourism enterprises of Los Tuxtlas in formally established networks, in the past and present, and the concrete working relation- 
ships which exist in the present. With a few exceptions, most of the networks are limited to the San Martín subregion, while La Voz del Río is limited to the Santa Marta subregion.

The oldest network, RECT (Network of Community-based Ecotourism of Los Tuxtlas), established in 2000, still exists. However, after having started with the participation of four community-based enterprises, several rural tourism enterprises and assistance from Nanciyaga, it has recently shrunk to only two members. RITA (Indigenous Network of Alternative Tourism) is another network which started to include ecotourism enterprises in the region in 2008. It is a national network, started in 2002, based on the connection between regional networks (UNDP 2012). Jomxuk was involved only for a short time, but

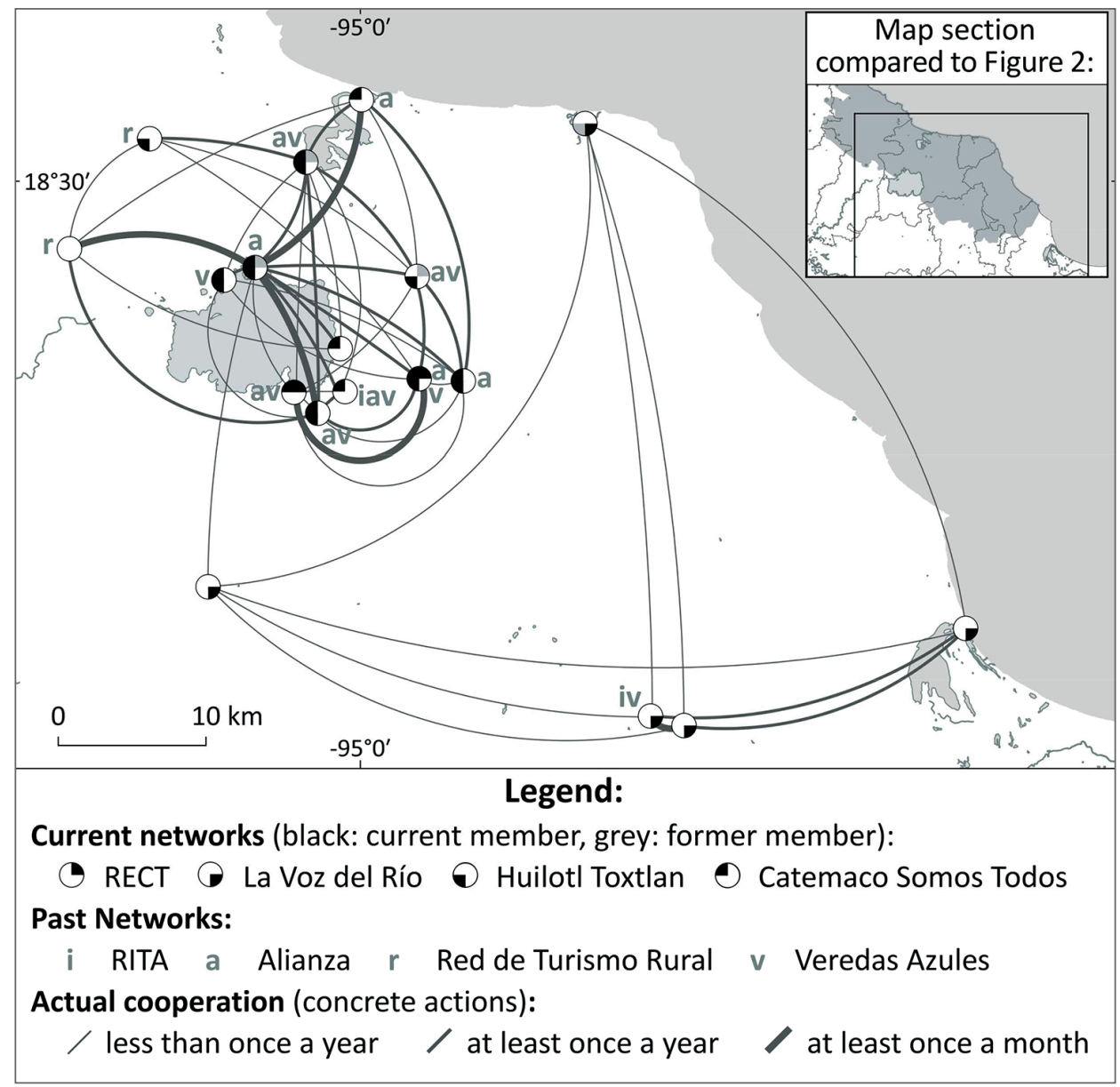

Source: Prepared by the authors, based on fieldwork and data from Instituto Nacional de Estadística y Geografía (2013b)

Figure 3: Formal networks and actual cooperation between ecotourism enterprises in Los Tuxtlas in 2017 
Cascadas Encantadas participated regularly for several years as well as four indigenous ecotourism enterprises, which have been abandoned by now. Nowadays, RITA isn't present in Los Tuxtlas anymore.

Two networks which only existed for a short time were Alianza de Prestadores de Servicios Ecoturísticos de la Selva de Los Tuxtlas ("Alliance of Ecotourism Service Providers of the Forest of Los Tuxtlas', subsequently: Alianza), from 2011 to 2012, and Red de Turismo Rural Sustantable de San Andrés Tuxtla ('Network of Sustainable Rural Tourism of San Andrés Tuxtla', subsequently: Red de Turismo Rural), only for several months in the year 2014. The former included most of the ecotourism enterprises and some other tourism firms in Catemaco, while the latter was restricted to enterprises in the municipality San Andrés Tuxtla, including Yambigapan and Los Clarines as well as several other tourism firms in rural communities.

The network Huilotl Toxtlan was started in 2011, originally as a citizen science project involving people from local communities in the monitoring of birds. Several of its participants belong to both private and community-based enterprises in the San Martín Tuxtla subregion; formerly also Los Arrecifes from the Santa Marta subregion participated. Since 2016 the network has received some small groups of birdwatching tourists. It is right now in the process of professionalising its organisation, including a stronger focus on tourism.

From 2014 to 2017, the network Veredas Azules included enterprises mainly from Catemaco, but also Jomxuk. By fall of 2017 it had already been abandoned. Another network initiated in 2014 still exists, La Voz del Río, which is limited exclusively to the five enterprises found in the municipalities of the Santa Marta subregion. Finally, the last new network, created in December of 2016, Catemaco Somos Todos, as its name suggests, is focussed on enterprises within Catemaco. With the exception of Selva del Marinero, all ecotourism firms in the municipality are taking part.

Figure 3 compares the formal networks to the actual cooperation, referring to the realisation of joint activities that go beyond the assistance in official network meetings. The activities mentioned with most frequency were exchange of experiences and information and capacity building workshops, promotion of the ecotourism enterprises among each other, joint representation of political interests and coordination of conservation efforts.

In the case of RECT and La Voz del Río, the participating enterprises are all working together in concrete activities; they are often only sporadic, though. In Huilotl Toxtlan, cooperation in ecotourism exists, but not in all cases. Participants usually have contacts to, on an average, 4.9 other members, out of 7 . In Catemaco Somos Todos, Nanciyaga is the only one which has ties to all other 10 participating ecotourism enterprises. For the rest of the participants, the average of relations is 5.8. There is no connection between Jomxuk and Cascadas Encantadas, which had both been part of RITA. However, there is still cooperation between the former members of Red de Turismo Rural, Yambigapan and Los Clarines. Regarding Alianza and Veredas Azules, former participants still are holding ties to about half of the their counterparts.

Cooperation also exists between enterprises which are not part of the same formal networks, as in the case of Yambigapan, which has a strong relationship to Nanciyaga and works regularly with Anolis as well. In general, cases of strong relationships are rare; 
they include the ties between Kan Tasejkan and Jomxuk, between Las Margaritas and El Apompal, and the cooperation of Nanciyaga with Los Amigos and Anolis.

The spatial visualisation of the connections of cooperation shows that there are basically two informal networks existing in Los Tuxtlas, one in the Santa Marta subregion, which corresponds to the formal network Red de la Voz del Río, and another informal network comprising all the enterprises in the San Martín subregion. The only connection between those two is the tie between Nanciyaga and Ceytaks. Therefore, regarding the social network measure of proximal betweenness, showing how often an actor is an intermediary in the shortest connection of other actors, Nanciyaga (with a value of 0.541 ) and Ceytaks (0.382), rank highest. All other enterprises have betweenness values lower than 0.1 . These two, accordingly, are holding the key to information exchange between the networks and a potential stronger integration between the northwestern and the southeastern part. At the moment, however, their cooperation is still only sporadic.

Nanciyaga is also ranking highest with regard to another social network measure, namely total degree $(0.706$, that means it has direct connections to $70.6 \%$ of the enterprises), which marks its prominent position. Other enterprises with relatively high total degrees are all located in the northwestern part, notably Manglares de Sontecomapan (0.529), Anolis (0.471), El Apompal and Selva del Marinero (both 0.412). The degree of Ceytaks is significantly lower (0.294), although it is still higher than that of the other indigenous ecotourism enterprises, which share the second lowest degree value (0.235) with Cascadas Encantadas, Los Amigos, Los Clarines and Yambigapan. The lowest degree is the one of Poza Reyna (0.176).

Especially due to the gap of connections between the northwestern and the southeastern part of Los Tuxtlas, the overall network's density is relatively low (32.8\% existing ties in comparison to the ties which would be possible). Looking at the two networks in separate, however, ignoring the link between Nanciyaga and Ceytaks, one would get a density of $50.0 \%$ for the northwest and of $100 \%$ for the southeast, which means a perfectly connected network with ties among all members. Yet it is important to note, as Figure 3 shows, that many of these ties are still very weak, implicating only sporadic cooperation.

With respect to centralisation, the overall value for the network is $57.5 \%$, which represents an intermediate value, neither highly centralised, dependent on a single actor, nor totally uncentralised (a network with a high centralisation index is usually considered being fragile, cp. RENDón et al. 2007). In the southeastern part the value of centralisation is 0 , which means that no central actor can be identified, all enterprises are equally connected. In the northwestern part, centralisation reaches a value of $55.4 \%$.

\subsection{Catalysts, obstacles and stakeholders involved}

Several of the formal networks presented in Figure 3 have involved other actors apart from the ecotourism enterprises. In many cases, the very impulse to create the network as well as its leadership has come from other stakeholders. Civil society has played an important role in this respect. The promoters of the network RITA, based in Mexico City, are themselves organised as a civil association. Both RECT and Alianza were initially 
impulsed by the civil association SENDAS ('Pathways and Encounters for a Sustainable Autonomous Development') in cooperation with different academic institutions. In the case of the RECT, the LTBR's administration and several private consultants helped with capacity building and promotion, too. Later on, these consultants set up a tour operator office in Mexico City and took over the network's leadership. In contrast to them, the other external actors gradually withdrew from the network.

Huilotl Toxtlan and Veredas Azules were both established by the LTBR's administration, the former in coordination with CONABIO ('National Commission for the Knowledge and Use of Biodiversity'), and Red de Turismo Rural was established by the municipal administration of San Andrés Tuxtla. Finally, La Voz del Río was established by the ecotourism enterprises themselves and the foundation of Catemaco Somos Todos was a joint effort of different tourism service providers in Catemaco, including hotels, restaurants, boatmen, and tour operators. Ecotourism enterprises played a leading role in the establishment of the network, especially Nanciyaga, and set up their own committee.

A catalyst for the establishments of the networks in several cases was the prospect of receiving public funding for capacity building or infrastructure (RECT, Alianza, Red de Turismo Rural, Veredas Azules). In the case of RITA, the enterprises in Los Tuxtlas were invited to participate in this nationwide indigenous tourism network after they had been funded by the CDI ("National Commission for the Development of Indigenous Peoples'). Capacity building activities organised by the CDI were also the platform where the members of the enterprises forming La Voz del Río got to know each other and decided to start the network. Finally, the foundation of Catemaco Somos Todos had an outstanding catalysing event: the municipal head town of Catemaco was struck by severe acts of vandalism, including the burning of parts of the town hall. This motivated the local tourism actors to get together in working on enhancing the municipality's damaged touristic image. Informal cooperation has often surged spontaneously, yet in some cases it is also the result of previous formal cooperation, as in the case of Yambigapan and Los Clarines or of the former members of Alianza, which four years later participated together in the formation of a new formal network, Catemaco Somos Todos.

The principal obstacles to networking in the region are the distances between the places where ecotourism is practiced, due to, on the one hand, its physical geography and, on the other hand, negligence of public administrations in the maintenance of rural roads. For example, Los Amigos and Los Arrecifes are located at an air-line distance of $15 \mathrm{~km}$. However, in order to get from one place to the other on roads suitable for passenger cars, one has to go $199 \mathrm{~km}$. The mean distance between all the ecotourism enterprises is $73 \mathrm{~km}$. Within the San Martin subregion, the mean distance to get from one ecotourism centre to another is $26 \mathrm{~km}$. In the Santa Marta subregion, where the most peripheral firms are found, distances are much higher, with a mean of $69 \mathrm{~km}$. Los Arrecifes is located $60 \mathrm{~km}$ from the closest other centre, Kan Tasejkan. Ceytaks is actually closer to firms in the north-west, regarding road distance, at a minimum distance of $43 \mathrm{~km}$. Interestingly, as Figure 3 shows, both firms are the only ones which have no regular connection to any other firm. In the interviews, one representative also mentioned the cost of transport for attending meetings as one of the main reasons he withdrew from a network. 
In contrast to that, close distance clearly enforces networking. This is evidenced both by the strong relations between closely located firms like Kan Tasejkan and Jomxuk, which are located at only $4 \mathrm{~km}$ from each other, and by the position of Nanciyaga, which scores highest of all network centrality measures and, with $47 \mathrm{~km}(18 \mathrm{~km}$ to other enterprises in the San Martín subregion), is also the enterprise with the second lowest mean distance to other enterprises. However, short distance does not always constitute strong cooperation. For instance, Xococapan, which lies at little more than $1 \mathrm{~km}$ of Nanciyaga and is, by road distance, the most central enterprise of all, has much lower scores regarding network centrality and no strong connections. Relationships are also very weak between Anolis and Cascadas Encantadas, located in the same village, and Las Margaritas, at a distance of less than $1 \mathrm{~km}$ of the former, as well as in the case of El Apompal and La Otra Opción, both located at a distance of $8 \mathrm{~km}$.

Here another factor appears to come into play, as mentioned in chapter 2, the factor of trust. In general, between enterprises working closely together, levels of trust are high. They were measured in the questionnaire on a scale of 5 for high trust to 0 , which means no trust at all. The latter can be due to bad experiences or prejudice, or due to the fact that the representatives of the different enterprises do not know each other at all, as is often the case with enterprises in the northwestern and the southeastern part. The highest rate of trust is attributed to Nanciyaga, a mean rate of 3.6, while Rancho Xococapan, for instance, has a mean rate of only 1.0. Results from the interviews make it clear that, while networking in fact increases trust, the complete absence of trust impedes starting to work together in the first place. This is the case with the enterprises located very closely as mentioned above, where a high sense of competition has led to subliminal conflicts. The low degree of cooperation between these firms is all the more noticeable, as all of them have participated together in formal networks.

Trust is also cited frequently in the interviews as an important factor in the leadership of formal networks. Leaders seeking primarily the self-interest of their own enterprise were named as a problem by two representatives. However, other interviewees opined that unjustified critique of leaders presented an obstacle to the networking processes, too. In RITA, Jomxuk narrated having left the network due to a conflict over its leadership. One representative proposed that there should be a formalised process to select leaders, making sure they have the required capacities.

Related to the question of leadership, the withdrawal of some of the participants of the RECT was caused mainly by the relation between the local enterprises and the involved tour operator in Mexico City, which was perceived as being unfair and uneven. The only enterprises still staying in RECT are those which, owing to a lack of means of communication and knowledge (related to low levels of education), are dependent on working with the tour operator (cp. JuÁrez 2016). Red de Turismo Rural and Veredas Azules came to an end because in both cases the governmental agencies which had promoted them, due to internal changes, dismissed the official in charge of the networks and stopped their financial support. In the case of Alianza, initial support by an NGO and a university ceased due to lack of financial resources as well.

In RITA, besides Jomxuk, the other members left the network since they didn't see the short or medium term results they had expected like a stronger visitor flow or fund- 
ing. This was also the reason for the abandonment of Alianza, together with incapacity to define common goals, related to the fact that one of the leaders of Alianza was a hotel, owned by a person from outside the region, whose operations, according to the opinion of one interviewee, were not in accord with ecotourism. In Red de Turismo Rural and Veredas Azules, the participants' interest and commitment had already diminished because of the lack of defining common goals too, even before the official end of these networks. Jomxuk had abandoned Veredas Azules early on, dissatisfied with the missing discipline of the other participants to attend to meetings. In Catemaco Somos Todos, the ecotourism enterprises kept working together by the time of the end of the fieldwork period of the present investigation; hotels and restaurants, however, had left the network due to internal conflicts, a high sense of competition, and, again, dissatisfaction with the lack of short term results.

\subsection{Costs and benefits}

Regarding costs and benefits, the clearly most beneficial experience for ecotourism centres in the region has been the RECT in the first years of its existence, which provided the community-based firms, which were still in a state of formation, with governmental funding for capacity building, infrastructure and certification of the quality of their services. Later, however, the involvement of the tour operator was seen as more and more detrimental to the enterprises' independence and economic success. This has discouraged other firms from entering the network and led to the withdrawal of two of its members. One of them, Selva del Marinero, in 2016 was the only ecotourism enterprise, which didn't want to enter Catemaco Somos Todos, due to the bad experience its members had lived in the RECT.

In several other networks (RITA, Alianza, Red de Turismo Rural, Huilotl Toxtlan), the main benefit was the facilitation of courses which helped the firms to enhance the quality of their services and consolidate their tourism offer. Additionally, in Alianza, Huilotl Toxtlan, Veredas Azules and Catemaco Somos Todos some short term promotion activities could be carried out in a cooperative manner, like the participation in tourism fairs and the elaboration of folders. Catemaco Somos Todos also seems to have strengthened political influence, achieving that tourism, which in previous years had been widely ignored by the local administration, was recognised as an important topic by most candidates of the local elections.

Furthermore, the formal networks have served as a platform for the initiation of informal relations between the actors involved, which are sometimes continued despite the general abandonment of the network. The ecotourism section of Catemaco Somos Todos, finally, was the result of previous formal and informal cooperation of the ecotourism enterprises. While the owners of hotels and restaurants proved unable to work together, the ecotourism firms drew from their previous experiences and learnings, which allowed them to continue in the network and realise concrete actions.

The most prevalent activity of informal cooperation is, again, conjoint participation in capacity building activities and the exchange of experiences and information, present in 
$81.1 \%$ of the actual ties between the ecotourism enterprises. The second most common activity is informal promotion of the other firms with visiting tourists, which is present in $64.2 \%$ of the ties. This includes presentation of promotional material and in some cases assistance with reservation and the organisation of transport. In only four cases, $7.5 \%$ of the total ties, the enterprises have even created collaborative tourism products, combining their individual offer.

Beside the experiences in the RECT, the representatives of the ecotourism firms involved in the networking processes didn't mention any negative outcomes. Several of the efforts to create formal networks, however, were criticised by many participants as having been a waste of time. Several of the networks, after some concrete activities at the beginning, started to consist solely of meetings without any results, and were forthwith abandoned. Nevertheless, the ecotourism firms in general have kept their interest in formal cooperation, which is apparent by the fact that by 2017 only one enterprise didn't participate in any formal network. In the case of the newest networks, there are still few visible effects, yet most participants mentioned that they have learned that these are processes which take their time.

\section{Conclusions}

The combination of both quantitative and qualitative research methods has proved fruitful for the present investigation. Data from questionnaires have allowed it to visualise the existing connections between the ecotourism enterprises and to calculate which actors are most involved in networking and hold the most prominent position. Qualitative data have provided a more profound understanding of how these relationships have come into place and have been shaped by different factors which catalyse or restrain the networking processes. In this context, cartographic visualisation of the data made it clear that spatial distances play an important role in the configuration of the networks.

Out of eight formal networks, which have been established in Los Tuxtlas over the last two decades, only four still existed by late 2017. Most of them were of recent creation; only RECT exists since 2000 but has shrunk to only two participants. However, this doesn't mean that previous efforts to create formal networks in the region had been in vain. Most of them served as a platform for capacity building, which has brought about long term benefits for the participating enterprises. Furthermore, they facilitated an opportunity for the ecotourism enterprises to get to know each other and initiate informal ways of working together, which are now an integral part of the day-to-day practice of several of the ecotourism firms. This kind of informal cooperation is mainly focussed on information exchange and mutual promotion.

Yet formal cooperation still seems to be necessary for objectives which can be reached only by larger groups of actors, like promotion on a larger scale, or common representation of political interests. In this regard, networking has brought about small benefits for the ecotourism enterprises, yet for being able to significantly enhance the economic sustainability of the enterprises, a strong and, most importantly, more continuous formal networking process would be necessary. 
Most networks have been created and led by external actors, both from civil society and the government. However, these efforts have usually been short-lived, due to the discontinuity of Mexican political institutions and, subsequently, of the work of civil associations and academic institutions dependent on public funding. Therefore, the majority of the representatives of the enterprises now coincide, that ecotourism networks should basically be led by the enterprises themselves. Other stakeholders might assist, but the persistence of the networking process shouldn't depend on them, as it is practiced in the two newest networks founded in the region.

Working together with other tourism service providers like conventional hotels has mostly proven unsuccessful, too, both due to different objectives and lack of trust. Trust has proven to be a key element for networking and for developing an effective leadership within the ecotourism enterprises as well. Problems with leadership of networks are due to leaders seeking primarily their own interests, conflicts over leadership, but also unjustified criticism of persons in leading positions.

Despite these difficulties, several enterprises have developed a prominent position, regarding their centrality in the regional net of connections between the enterprises, which is related both to their geographic location and accessibility and to a high degree of trust they inspire in the other enterprises, most prominently Nanciyaga in the northwestern part of Los Tuxtlas. So far, there have been no successful attempts to integrate the whole region. Ceytaks, in this case, would hold the key of being in an intermediate position between the two subregions; however, a stronger integration is unlikely to happen unless roads are repaired and improved, which would allow a better connectivity.

In general, learnings from the networking processes further include the realisation that participants should share clear common goals. In several networks, many enterprises took part hoping to receive funding or to carry out effective promotional activities, although the networks' main focus was rather creating basic conditions for a successful tourism product by means of capacity building. This misunderstanding has led to disappointment and withdrawal from the networks. The difficulty to share common goals has also frustrated attempts to build networks between ecotourism enterprises and other tourism service providers like conventional hotels.

Another important point, learning from the experience of the RECT, is that despite working together in a network, enterprises should maintain their independence, and that in case of creating combined products, a fair and transparent distribution of the income generated is crucial. Finally, official meetings should be related to concrete action in order not to be perceived as a waste of time. While working on long term goals, it may be helpful to ensure that networks also produce some short term results, which motivate the members not to give up.

\section{References}

BeCKer C. (2007): Destinationsmanagement [Destination management]. In: BeCKer C., Hopfinger H., Steinecke, A. (eds.): Geographie der Freizeit und des Tourismus [Geography of leisure and tourism], $3^{\text {rd }}$ edition. Munich, Oldenbourg Wissenschaftsverlag, pp. 464-474. 
Comisión Nacional de Áreas Naturales Protegidas (CONANP) (2006): Programa de Conservación y Manejo: Reserva de la Biosfera Los Tuxtlas [Conservation and management programme: Los Tuxtlas Biosphere Reserve]. Mexico City, Comisión Nacional de Áreas Naturales Protegidas.

Comisión Nacional de Áreas Naturales Protegidas (CONANP) (2015): Que hacemos: áreas protegidas decretadas [What we do: decreed protected areas]. - http://www.conanp.gob.mx/ que_hacemos (accessed Sept. 20, 2015).

Consejo Nacional de Evaluación de la Política de Desarrollo Social (CONEVAL) (2017): Pobreza a nivel municipal 2010 y 2015 [Poverty on the municipal level 2010 and 2015]. - http://www. conevalorg.mx/Medicion/Paginas/Pobreza-municipal.aspx (accessed Dec. 12, 2017).

Díaz-Carrión I. A., Neger C. (2014): Ecotourism in the Reserva de la Biosfera de Los Tuxtlas (Veracruz, Mexico). In: Athens Journal of Tourism, 1, 3, pp. 191-202.

DunN K. (2010): Interviewing. In: HAY I. (ed.): Qualitative Research Methods in Human Geography, $3^{\text {rd }}$ edition. Ontario, Oxford University Press, pp. 101-138.

Eisenstein B. (2014): Grundlagen des Destinationsmanagements [Fundaments of destination management], $2^{\text {nd }}$ edition. Munich, Oldenbourg Wissenschaftsverlag.

Farrell B. H., Runyan D. (1991): Ecology and Tourism. In: Annals of Tourism Research, 18, 1, pp. 26-40.

FenNell D. A. (1999): Ecotourism. Abigdon, Routledge.

FREYER W. (2006): Tourismus: Einführung in die Fremdenverkehrsökonomie [Tourism: introduction to tourism economy]. Munich, Oldenbourg Wissenschaftsverlag.

Geissert K. (2004): La Geomorfología [The geomorphology]. In: Guevara S., Laborde J., SÁnchez-Ríos, G. (eds.): Los Tuxtlas: el paisaje de la sierra [Los Tuxtlas: the landscape of the mountains]. Xalapa, Institute of Ecology, pp. 159-178.

Gutiérrez-García G., Ricker M. (2011): Climate and Climate Change in the Region of Los Tuxtlas (Veracruz, Mexico): A Statistical Analysis. In: Atmósfera, 24, 4, pp. 347-373.

Guevara S., Laborde J., SÁnchez-Ríos G. (2004): Los Tuxtlas: el paisaje de la sierra [Los Tuxtlas: the landscape of the mountains]. Xalapa, Institute of Ecology.

Hall C. M., Lynch P., Michael E. J., Mitchell, R. (2007): The Contribution of the Micro Cluster Approach. In: Michael, E. J. (ed.): Micro-Clusters and Networks: The Growth of Tourism. Oxford, Elsevier, pp. 141-152.

Honey M. (2008): Ecotourism and Sustainable Development: Who Owns Paradise? $2^{\text {nd }}$ edition. Washington, Island Press.

Instituto Nacional de Estadística y Geografía (INEGI) (2013a): Continuo de Elevaciones Mexicano 3.0 [Mexican continuum of elevations 3.0]. - http://www.inegi.org. $m x / g e o / c o n t e n i d o s / d a-$ tosrelieve/continental/continuoelevaciones.aspx (accessed Nov. 10, 2017).

Instituto Nacional de Estadística y Geografía (INEGI) (2013b): Principales resultados por localidad (ITER) del Censo de Población y Vivienda 2010 [Main results per locality (ITER) of the census of population and housing 2010]. - http://www.beta.inegi.org.mx/proyectos/ ccpv/2010/default.html (accessed Dec. 7, 2017).

Instituto Nacional de Estadística y Geografía (INEGI) (2016a): Marco Geoestadístico, Junio 2016 [Geostatistic framework, June 2016]. - http://www. beta.inegi.org.mx/app/biblioteca/ficha. html? upc $=702825217341$ (accessed Dec. 8, 2017).

Instituto Nacional de Estadística y Geografía (INEGI) (2016b): Anuario estadístico y geográfico de Veracruz de Ignacio de la Llave 2016 [Statistical and geographic yearbook of Veracruz de Ignacio de la Llave 2016]. - http://www.veracruz .gob.mx/finanzas/files/2017/01/AEyGE2016.pdf (accessed Dec. 12, 2017).

JAFARI J. (2001): The Scientification of Tourism. In: Smith V. L., Brent, M. (eds.): Hosts and Guests Revisited: Tourism Issues of the $21^{\text {st }}$ Century. New York, Cognizant, pp. 28-41. 
JuÁREZ, L. E. (2016): Proceso de adopción, adaptación y apropiación de una propuesta de ecoturismo en cuatro comunidades en la Reserva de la Biosfera Los Tuxtlas, Veracruz [Process of adoption, adaptation and appropiation of an ecotourism proposal in four communities in the Los Tuxtlas Biosphere Reserve, Veracruz]. Master's thesis, National Autonomous University of Mexico, Institute of Social Research.

Косн N., KüнN A. (2011): Ein Sozialfestival gegen Armut und für regionale Identität - eine netzwerkanalytische Untersuchung im Lungau [A social festival against poverty and for regional identity - a network analysis investigation in the Lungau]. In: Mitteilungen der Österreichischen Geographischen Gesellschaft, 153, pp. 165-198.

LeIN, J. T. W. (2011): Akzeptanzschaffung für Biosphärenreservate durch Ökotourismus - eine Analyse der Wahrnehmung des Biosphärenreservates Los Tuxtlas, Mexiko, durch lokale Ökotourismusbetriebe [Creating acceptance for biosphere reserves through ecotourism an analysis of the perception of the Los Tuxtlas Biosphere Reserve, Mexico, among local ecotourism enterprises]. Master's thesis, University of Greifswald, Faculty of Mathematics and Natural Sciences.

López G., Palomino B. (2008): Políticas públicas y ecoturismo en comunidades indígenas de México [Public policies and ecotourism in indigenous communities of Mexico]. In: Teoría y Praxis, 5, pp. 33-50.

Lynch P., Morrison A. (2007): The Role of Networks. In: Michael, E. J. (ed.): Micro-Clusters and Networks: The Growth of Tourism. Oxford, Elsevier, pp. 43-78.

Michael E. J., Hall C. M. (2007): A Path for Policy. In: Michael, E. J. (ed.): Micro-Clusters and Networks: The Growth of Tourism. Oxford, Elsevier, pp. 127-140.

Neger C. (2013): Die Rolle des Ökotourismus für die Nachhaltige Entwicklung einer Region: Fallstudien aus Los Tuxtlas/Mexiko [The role of ecotourism for a region's sustainable development: case studies from Los Tuxtlas/Mexico]. Master's thesis, University of Graz, Department of Geography and Regional Science.

PARÉ L., LAZos E. (2003): Escuela rural y organización comunitaria: instituciones locales para el desarrollo y el manejo ambiental [Rural school and community organisation: local institutions for development and environmental management]. Mexico City, National Autonomous University of Mexico.

PARnReITER C. (2018): Geografía Económica: una introducción contemporánea [Economic geography: a contemporary introduction]. Mexico City, National Autonomous University of Mexico.

PiÑAR-Állvarez A. (2011): Gobernanza ambiental en destinos turísticos de áreas naturales protegidas: Reservas de la Biosfera Los Tuxtlas (Veracruz, México) y Sierra Nevada-La Alpujarra (Andalucía, España) [Environmental governance in tourism destinations in protected natural areas: biosphere reserves Los Tuxtlas (Veracruz, Mexico) and Sierra Nevada-La Alpujarra (Andalusia, Spain)]. Xalapa, El Colegio de Veracruz.

Proyecto Sierra de Santa Marta (PSSM) (2011): Actualización de la tasa de cambio del uso del suelo en la Reserva de la Biosfera Los Tuxtlas, reporte final [Actualisation of the rate of land use change in the Los Tuxtlas Biosphere Reserve, final report]. Xalapa, Comisión Nacional de Áreas Naturales Protegidas, Dirección Regional Planicie Costera y Golfo de México.

Rendón R., Aguilar J., MuÑoz M., Reyes J. (2007): Identificación de actores clave para la gestión de la innovación: el uso de redes sociales [Identification of key actors for the management of innovation: the use of social networks]. Texcoco, Chapingo Autonomous University.

Saldaña A., León K., Cardoso C. (2012): El agrupamiento empresarial de Jalcomulco, Veracruz: la institucionalización de un modelo de negocio en el turismo de aventura en México [The enterprise grouping of Jalcomulco, Veracruz: the institutionalisation of a business model in adventure tourism in Mexico]. In: Ciencia Administrativa, 2, pp. 25-36. 
SARetzKi A., Wilken M., WöHLer K. (2002): Lernende Tourismusregionen. Vernetzung als strategischer Erfolgsfaktor kleiner und mittlerer Unternehmen [Learning tourism regions: networking as a strategic success factor for small and medium-size enterprises]. Münster, LIT Verlag.

Secretaría de Turismo (SECTUR), Centro de Estudios Superiores en Turismo (CESTUR), Universidad Autónoma Metropolitana (UAM) (2007): Elementos para Evaluar el Impacto Económico, Social y Ambiental del Turismo de Naturaleza en México [Elements for evaluating the economic, social and environmental impact of nature tourism in Mexico]. Mexico City, Secretaría de Turismo.

Ter Wal A. L. J., Boschma R. A. (2009): Applying Social Network Analysis in Economic Geography: Framing Some Key Analytic Issues. In: The Annals of Regional Science, 43, 3, pp. 739-756.

TöLle A. (2012): Transnationale Netzwerkräume statt vernetzter Grenzregionen: Die Europaregion Mitte (Centrope) und die Oder-Partnerschaft [Transnational network spaces instead of interconnected border regions: the Central European Region (Centrope) and the Oder Partnership]. In: Mitteilungen der Österreichischen Geographischen Gesellschaft, 154, pp. 129-154.

United Nations Development Programme (UNDP) (2012): Indigenous Tourism Network of Mexico, Mexico. Equator Initiative Case Study Series. New York. - https://wwwequatorinitiative. org/wp-content/uploads/2017/05/case_1348164210.pdf(accessed Sept 27, 2018).

United Nations Environmental Programme (UNEP), World Tourism Organization (UNWTO) (2005): Making Tourism More Sustainable: a Guide for Policy Makers. - http://www.unep. fr/shared/publications/pdf/dtix0592xpa-tourismpolicyen.pdf (accessed Dec. 13, 2017).

United Nations Educational, Scientific and Cultural Organization (UNESCO) (1996): Biosphere Reserves: the Seville Strategy and the Statutory Framework of the World Network. - http:// unesdoc.unesco.org/images/0010/001038/103849 Eb.pdf (accessed Aug. 26, 2014).

World Tourism Organization (UNWTO), United Nations Environmental Programme (UNEP) (2002): World Ecotourism Summit: Final Report. Madrid, World Tourism Organization.

VARISCo C. (2007): Sistema Productivo Turístico y Desarrollo Local [Tourism production system and local development]. In: Ciencias Sociales Online, 4, 2, pp. 15-36.

Viken A. (2014): Destination Discourses and the Growth Paradigm. In: Viken A., GranÅs B. (eds.): Tourism Destination Development: Turns and Tactics, pp. 21-46. Farnham, Ashgate.

Weaver D. (2006): Sustainable Tourism: Theory and Practice. Oxford, Elsevier Butterworth-Heinemann.

Zehrer A., Raich F. (2010): Applying a Lifecycle Perspective to Explain Tourism Network Development. In: The Service Industries Journal, 30, 10, pp. 1683-1705. 